\title{
Influence of the Technological Inputs on the Resilience Capacity of the Viticultural Ecosystems
}

\author{
Adrian ŞERDINESCU*, Marian ION, Liliana PÎRCĂLABU \\ Research and Development Institute for Viticulture and Enology Valea Călugărească, Valea Mantei \\ street, No. 1, Postal code: 107620, Valea Călugărească, România \\ *)Corresponding author, e-mail: serdinescuadrian@yahoo.com
}

BulletinUASVM Horticulture 73(1) / 2016

Print ISSN 1843-5254, Electronic ISSN 1843-5394

DOI:10.15835/buasvmcn-hort:11477

\begin{abstract}
The viticultural ecosystem evolved during the time toward an industrial ecosystem in which the man acquired an efficient regulatory function. To estimate the tolerance of the ecosystem to the impact of anthropic factors it was introduce the concept of the resilience capacity. The aim of this study was to establish, by using this concept, the influence of soil maintenance system, fertilization system and plant protection system on the functionality of the viticultural ecosystems. The resilience capacity was estimated using 5 specific indicators: the constancy of fruitfulness, the productivity of vines, the quality of the yield, the plants health and the abundance of the useful entomofauna. To quantify the resilience capacity, the coefficient of variation of these indicators was used. It was considered that for a normal functionality of the ecosystem is acceptable a coefficient of variation of maximum $15 \%$ for the first three indicators and of $30 \%$ for the last two ones. This capacity was generally ensured in case of fertilization system and partially in case of soil maintenance and plant protection systems. Some technological variants, such as the permanent herbage and the chemical and biological protection treatments induced an overcome of the coefficient of variation concerning the constancy of fruitfulness and the productivity of vines, in the first case, and on the level of useful entomofauna and plants health in the second case. In order to prevent an irreversible disequilibrium in the functionality of the viticultural ecosystems we must allocate the technological inputs within the accepted limits of the resilience capacity.
\end{abstract}

Keywords: ecosystem, resilience capacity, technological links

\section{INTRODUCTION}

The viticultural ecosystem evolved during the time toward an industrial ecosystem in which the man acquired an efficient regulatory function. In these circumstances the ecosystem functioning and implicitly its productive capacity can be affected in a negative way by the technological inputs (Dejeu and Matei, 1996; Fregoni, 1998; Avenard et al., 2003; Cozzolino, 2004). To estimate the tolerance of an agricultural ecosystem to this impact it was introduce the concept of the resilience capacity. Resilience represent the capacity of an ecosystem to absorb or withstand perturbations and other stressors such that it remains with the same regime, essentially maintaining its structure and functions, without the appearance of an irreversible disequilibrium (Peterson et al., 1998: Gunderson, 2000; Motcă, 2005; Motcă et al., 2008; Brand, 2009). This capacity practically defines the range of variability of the volume and intensity of the anthropic factors within the equilibrium of the ecosystem is preserved, the ecosystem being able to absorb the variability induced by these factors by an internal reorganization process. The importance of this problem has lead to the creation of the Resilience Alliance, a research organization that focuses on resilience in socialecological systems as a basis for sustainability. This concept was introduce recently also in the field of viticulture and wine industry being related to the terroir sustainability (Flint et al., 2011; Lereboullet, 2013). 
The aim of the present study was to establish, by using this concept, the influence of the main technological links, respectively the soil maintenance system, the fertilization system and the plant protection system on the functionality of the viticultural ecosystem, in order to allocate these inputs at a level that ensures the prevention of an irreversible disequilibrium, which can affect the productivity of the ecosystem and also the quality of the environment.

\section{MATERIALS AND METHODS}

The researches carried out between 20102012 in Valea Călugărească winegrowing center in vineyards cultivated with the variety Riesling italian/ SO4, with planting distances $2.0 \times 1.0 \mathrm{~m}$ and bilateral cordon as training system. The fruit load was 17 eyes/sqm for all the variants. It was taken into study three different sub-types of the viticultural ecosystem, respectively the vineyards placed on terraced hills, on hills without terraces and on the plateau conditions. There were experimented the following technological links:

- Plant protection system, with three graduations: chemical protection, integrated protection and biological protection (each of them with 7 treatments, applied during the vegetative period);

- Soil maintenance system, with four graduations: black furrow, black furrow + selective use of herbicides, permanent herbage and soil mulching;

- Fertilization system, with four graduations: unfertilized, organic fertilization, chemical fertilization (with optimal NPK doses) and organic-mineral fertilization.

The resilience capacity was estimated by using 5 specific indicators, respectively: the constancy of fruitfulness, the productivity of vines, the quality of the yield, the plants health and the abundance of useful entomofauna. There were realized determinations concerning the fertility coefficients (absolute and relative), the productivity indices (absolute and relative), the grape production and its quality (sugars and total acidity), the degree of attack (\%) on the leaves and grapes for mildew (Plasmopara viticola), oidium (Uncinula necator) and bunch rot (Botrytis cinerea) and the abundance of the useful entomofauna. The abundance of useful entomofauna, which represent the natural predators of the harmful insects, was determined during may and june, at interval of two weeks, by using specific techniques, such as: drapery technique, Barber trap, leaf samples method. Based on these determinations it was calculated the number of species and number of insect/ species. To quantify the resilience capacity of the ecosystems the coefficient of variation (CV\%) of these indicators was used. The $\mathrm{CV} \%$ represent the ratio between the standard deviation and the arithmetic mean of the coefficient values (Ceapoiu, 1968). It was considered that for a normal functionality of the ecosystem is acceptable a coefficient of variation of maximum $15 \%$ for the first three specific indicators and of maximum $30 \%$ for the last two ones.

\section{RESULTS AND DISCUSSION}

a) The resilience capacity of the viticultural ecosystem according to the plant protection system

Analyzing the values of the coefficient of variation (average values for the three types of ecosystems) one can notice that the maximum values of these coefficients didn't exceed the level of $15 \%$ for the constancy of fruitfulness, the productivity of vines and the quality of the yield (expressed by the sugar content of grapes) (Fig 1).

In case of the must acidity the coefficient of variation had high values, over the level of the resilience capacity ( $C V>15 \%$ ) because of the drought conditions registered during the experimental period, Riesling italian being a sensible variety to the climatic stress, especially when it was cultivated on hills without terraces. Concerning the plants health one can notice that the biological plant protection system induced an exceeding of the resilience capacity of the viticultural ecosystems for all the pathogens taken into study (mildew, oidium and bunch rot). This was due to a lower effectiveness of the products used in case of the biological plant protection system, as compared to those used in case of the chemical plant protection system (Fig. 2).

Referring to the abundance of the useful entomofauna it was found that only the biological plant protection system ensured agood abundance. As compared with this system the chemical and the integrated plant protection systems induced a diminution of the useful entomofauna with 29.3, respectively $26.4 \%$. For this reason the resilience capacity of the ecosystems was surpassed (CV 
$>30 \%$ ) in case of the chemical plant protection system (Fig. 3).

b) The resilience capacity of the viticultural ecosystem according to the soil maintenance system

Concerning the influence of the soil maintenance systems on the resilience capacity of the viticultural ecosystems the values of the coefficients of variation for the specific indicators were higher as compared with the plant protection system, indicating that the soil maintenance system had a higher impact on the functionality of the viticultural ecosystems (Fig. 4).

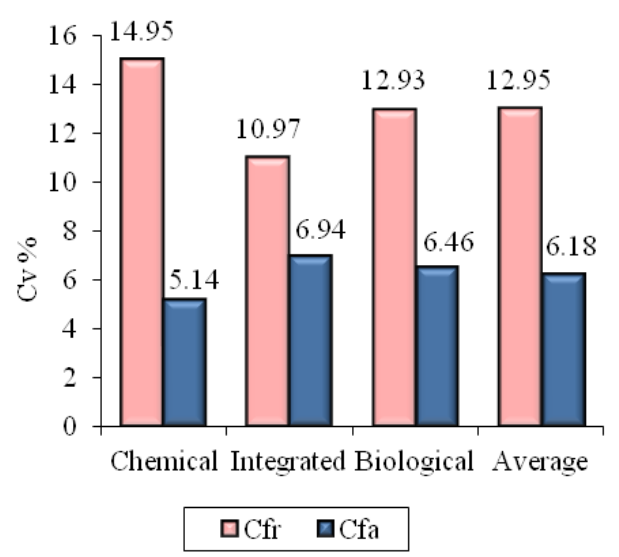

Indicator: Constancy of fruitfulness (expressed by the fertility coefficients)

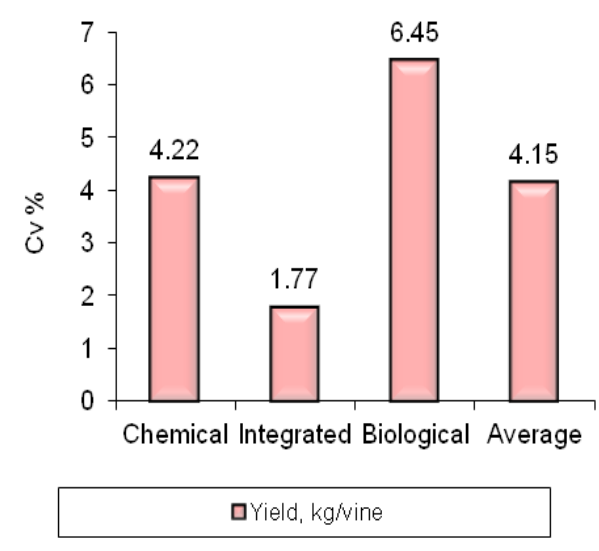

Indicator: Productivity of vines (expressed by the grapes yield)
Analyzing the values of the coefficients of variation we can notice that, generally speaking, the resilience capacity was ensured concerning the constancy of fruitfulness and the quality of the yield (only for sugar content of the grapes). Concerning the productivity of vines and the must acidity the coefficient of variation surpass the value of $15 \%$. During the three years of experimentation, characterized by drought conditions, the permanent herbage system had a negative impact on the constancy of fruitfulness and on the productivity of vines, this system emphasizing the effect produced by the drought conditions. Also, the must acidity was influenced in a negative way, having very low values. As

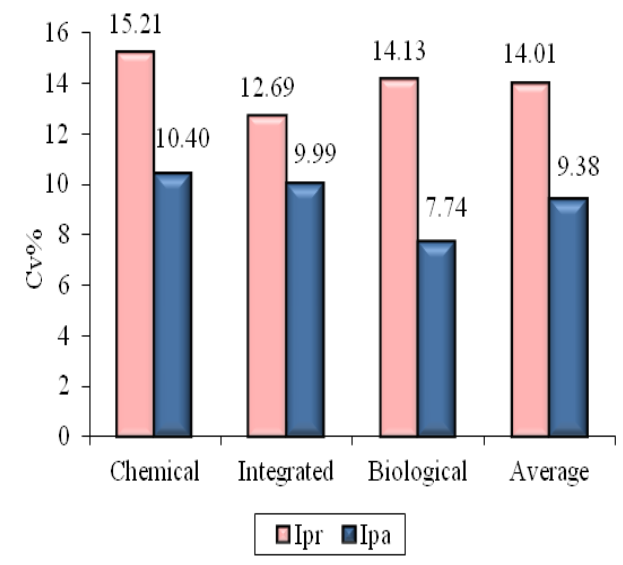

Indicator: Productivity of vines (expressed by the productivity indices)

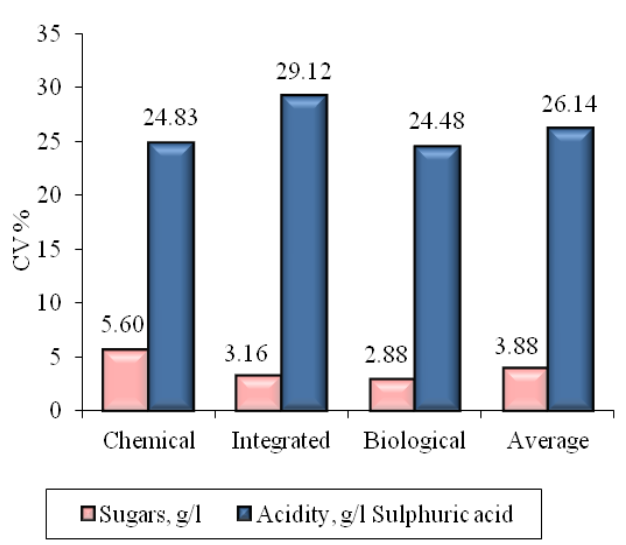

Indicator: Quality of the yield

Fig. 1. The values of the coefficients of variation for constancy of fruitfulness, the productivity of vines and the quality of the yield in case of the plant protection system (average values for the three types of ecosystems) 


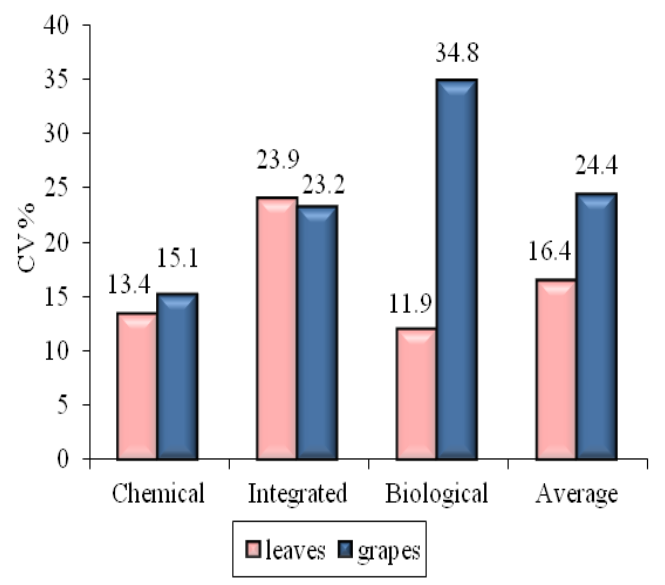

Indicator: Plants health in case of mildew (Plasmopara viticola)

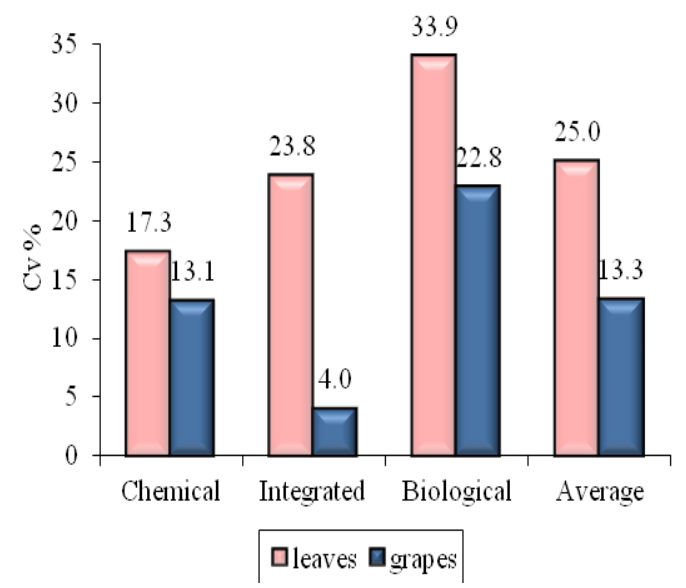

Indicator: Plants health in case of oidium (Uncinula necator)

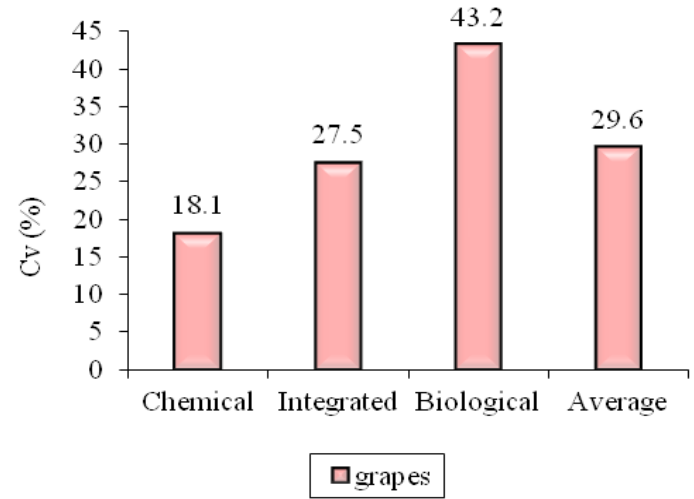

Indicator: Plants health in case of bunch rot (Botrytis cinerea)

Fig. 2. The values of the coefficient of variation concerning the plants health in case of plant protection system (average values for the three types of ecosystems)

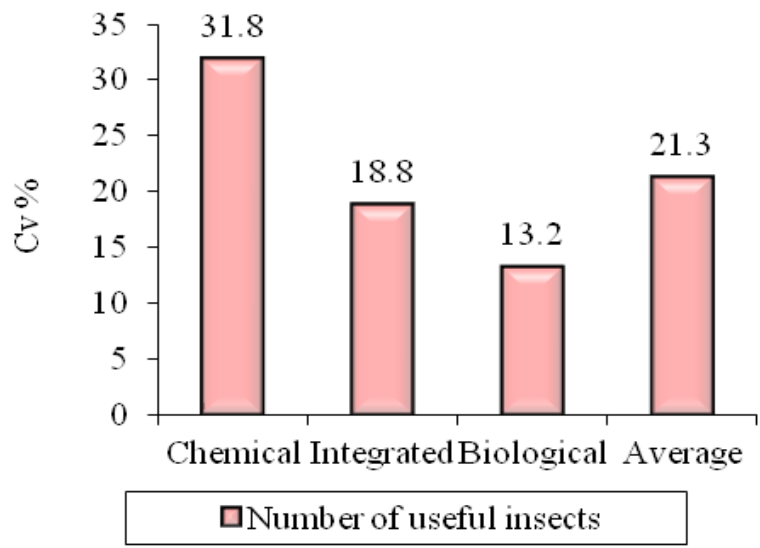

Indicator: Abundance of useful entomofauna

Fig. 3. The values of the coefficient of variation concerning the abundance of useful entomofauna in case of plant protection system (average values for the three types of ecosystems) 
contrary, the use of soil mulching system (with the remains of green fertilizers) had a positive effect on the constancy of fruitfulness and on the productivity of vines under drought conditions.

c) The resilience capacity of the viticultural ecosystem according to the fertilization system

In the domain of fertilization system the resilience capacity of the ecosystems was ensured, the values of the coefficients of variation being less than 15\% (Fig. 5).

The only exception was registered in case of the must acidity where the value of the coefficient of variation exceeds $15 \%$, because of the climatic conditions registered during the experiment and of the sensibility of Riesling Italian to the climatic stress. A positive influence on the constancy of fruitfulness and on the productivity of vines was induced by the organic and organic-mineral fertilization systems which ensured the higher yields. The lack of fertilization determined an surpass of the value of the coefficient of variation (CV $>15 \%$ ) for the indicator the productivity of vines (expressed by the values of the productivity indices) which highlights that the lack of fertilization can induce a disturbing effect on

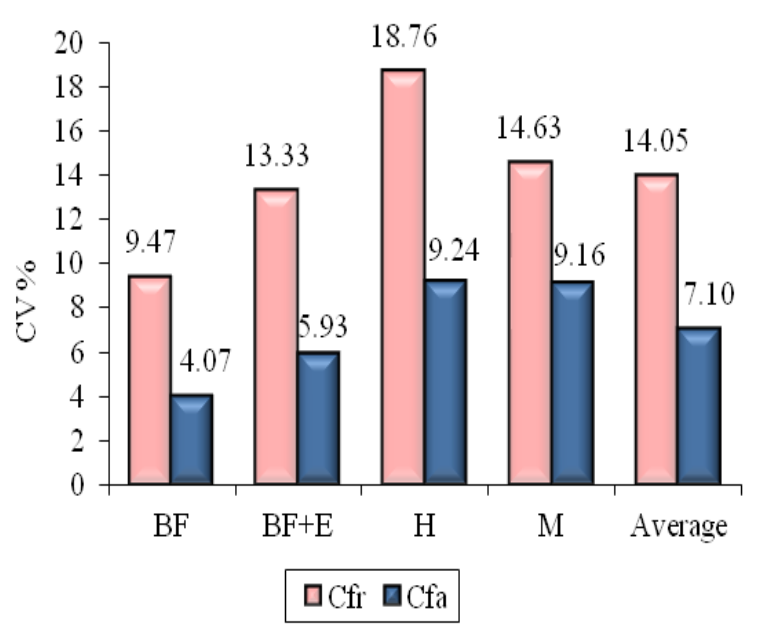

Indicator: Constancy of fruitfulness (expressed by the fertility coefficients)

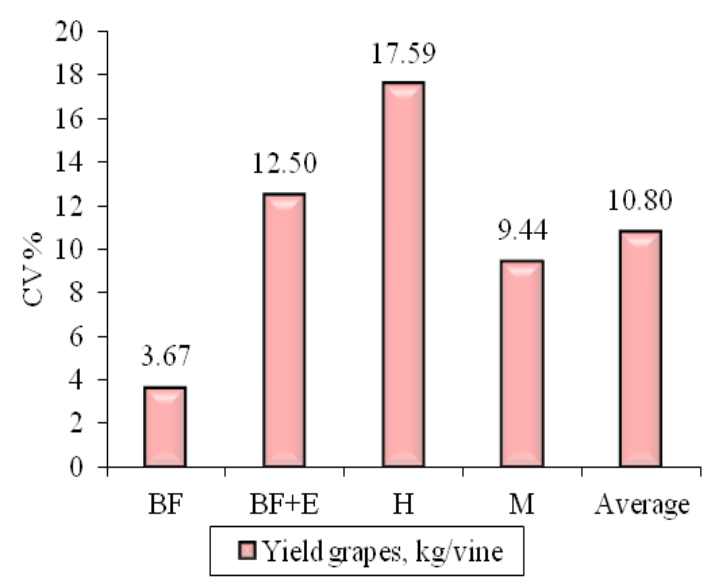

Indicator: Productivity of vines (expressed by the grapes yield)

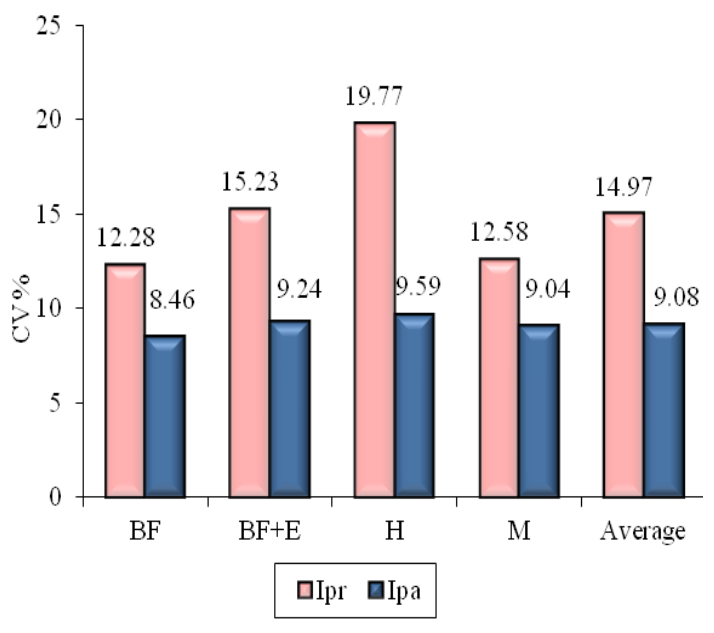

Indicator: Productivity of vines (expressed by the productivity indices)

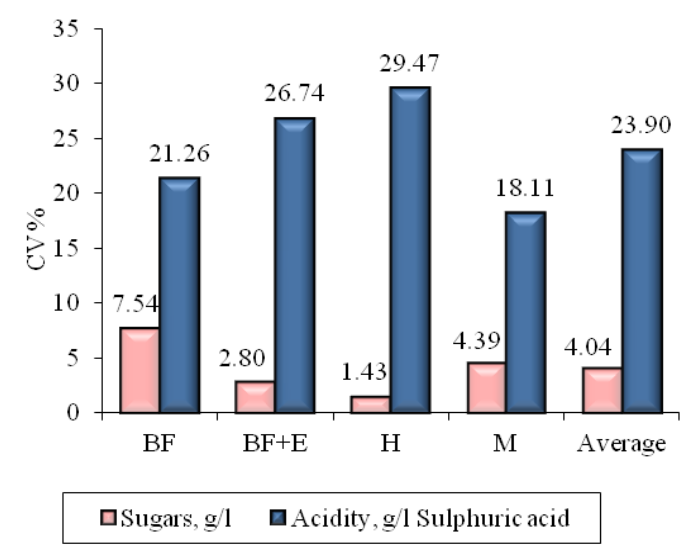

Indicator: Quality of the yield Legend: $\mathrm{BF}$ - black furrow; $\mathrm{BF}+\mathrm{E}$ - black furrow+selective use of herbicides; $\mathrm{H}$ - permanent herbage; $\mathrm{M}$ - soil mulching

Fig. 4. The values of the coefficients of variation for the constancy of fruitfulness, the productivity of vines and the quality of the yield in case of the soil maintenance system (average values for the three types of ecosystems) 
the functionality of the viticultural ecosystems, especially in case of stressed climatic conditions.

\section{CONCLUSION}

Being a long monoculture, the viticultural ecosystem shows some particularities, its productivity developing in accordance with the ecological resources and with the way in which these resources can be improved and fully valued by the main technological links (soil maintenance system, plant protection system and fertilization system),which must be harmonized with the resilience capacity of the ecosystem.

The experimented technological links had a differentially impact on the functionality and

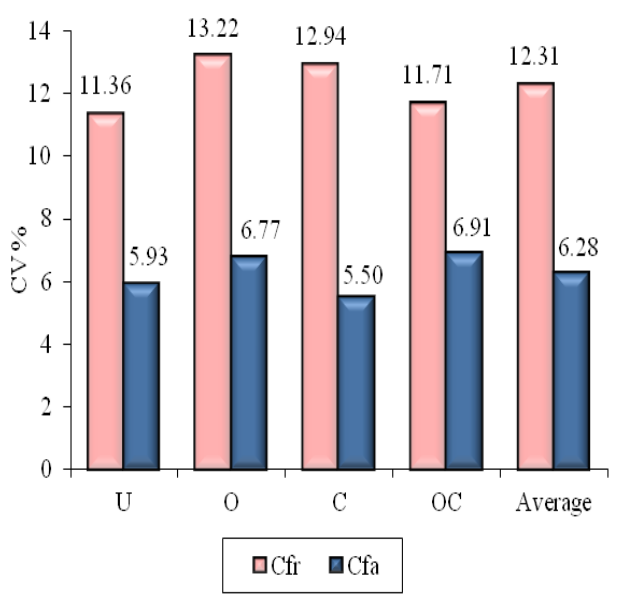

Indicator: Constancy of fruitfulness (expressed by the fertility coefficients)

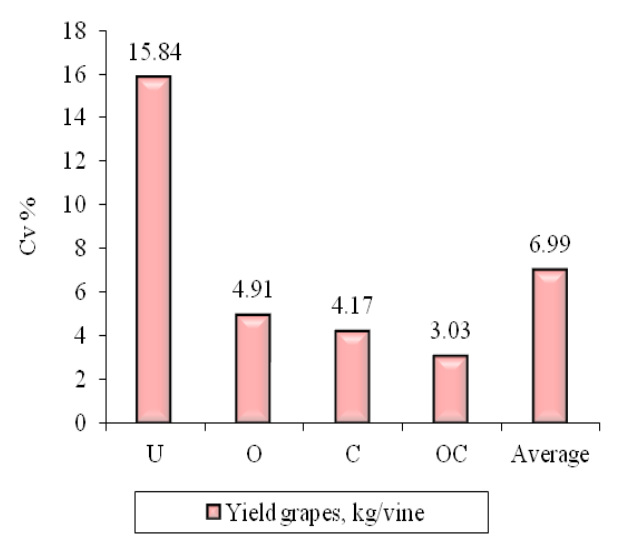

Indicator: Productivity of vines (expressed by the grapes yield) productivity of the three ecosystems taken into study, in accordance with the specific conditions of the biotope.

The resilience capacity of the viticultural ecosystems was provided (with some exceptions) in the field of the experimented factors, the coefficients of variation didn't exceed the maximum limits (15 or $30 \%$ ).

An overpass of the resilience capacity was noticed in case of the chemical protection for the indicator concerning the abundance of useful entomofauna and in case of the biological protection for the indicator concerning plants health. Also, an overpass of the resilience capacity was noticed in case of the permanent herbage

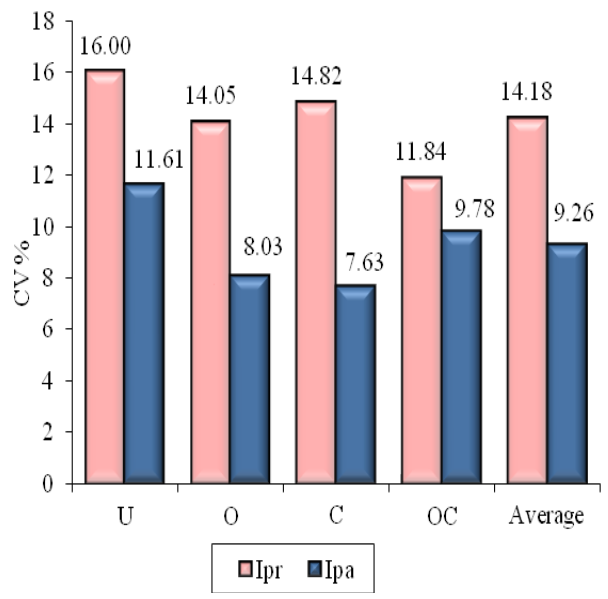

Indicator: Productivity of vines (expressed by the productivity indices)

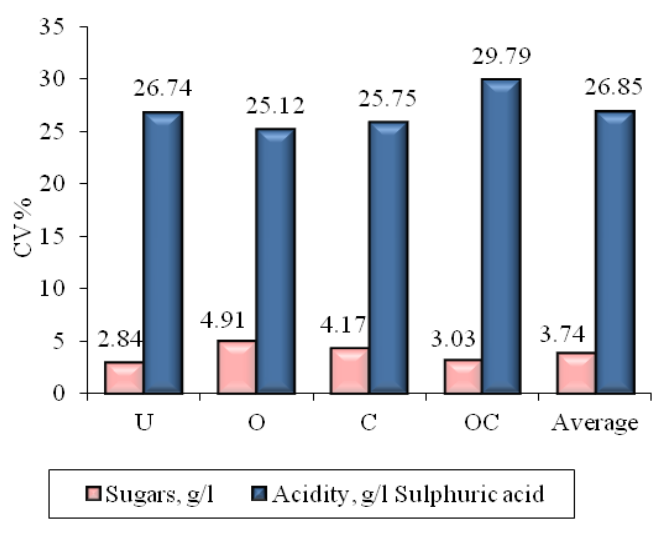

Indicator: Quality of the yield Legend: $\mathrm{U}$ - unfertilized; $\mathrm{O}$ - organic fertilization; $\mathrm{C}$ - chemical fertilization; OC - organic-chemical fertilization

Fig. 5. The values of the coefficients of variation for the constancy of fruitfulness, the productivity of vines and the quality of the yield in case of the fertilization system (average values for the three types of ecosystems) 
for the indicators concerning the constancy of fruitfulness and the productivity of vines (especially in drought conditions) and in case of unfertilized treatment for the indicator concerning the productivity of vines.

In order to prevent an irreversible disequilibrium in the functionality of the viticultural ecosystems we must allocate the technological inputs within the accepted limits of the resilience capacity of these ecosystems.

\section{REFERENCES}

1. Avenard JC, Bernos L, Grand O, Samie B (2003). Manuel de production intégré en viticulture. Ed. Feret, Bordeaux.

2. Brand F (2009). Critical natural capital revisited: Ecological resilience and sustainable development. Ecological Economics 68(3):605-612.

3. Ceapolu, N (1968). Metode statistice aplicate în experiențele agricole și biologice. Ed. Agro-Silvică,

4. Cozzolino E (2004). Viticoltura ed enologia biologica. Ed. Edagricole, Bologna.
5. Dejeu L, Matei P (1996). Viticultura biologică. Centrul Editorial Poligrafic USAMV, Bucuresti.

6. Flint DJ, Golicic SL, Signori P (2011). Sustainability through Resilience: The Very Essence of the Wine Industry. Pr. of the $6^{\text {th }}$ AWBR International Conference, Bordeaux

7. Fregoni M (1998). Viticoltura di qualita. Ed. Informatore Agrario SRL.

8. Gunderson LH (2000). Ecological Resilience. In Theory and Application. Annual Review of Ecology\& Systematics 31:425

9. Lereboullet AL (2013). How do Geographical Indications interact with the adaptive capacity and resilience of viticultural systems facing global change. Pr. of the XXVth ESRS Congress: 331-332.

10. Motcă Ghe (2005). Evaluarea capacitătiii de rezilientă a pajiștilor în sistemul utilizării multifuncționale. Sesiune stiintifică USAMV Bucuresti, Volum de rezumate: 89.

11. Motćă Ghe și colab. (2008). Reziliența ecosistemelor naturale cu vegetație ierboasă: concept și aplicabilitate. Lucrări științifice USAMV București, Seria A, Agronomie, vol. LI: 539-546.

12. Peterson G, Allen CR, Holling CS (1998). Ecological Resilience, Biodiversity and Scale. Ecosystems 1(1):618. 